\title{
Sposób rozstrzygnięcia o władzy rodzicielskiej w wyrokach rozwodowych w porównaniu z wyrokami orzekającymi separację w świetle badań aktowych ${ }^{2}$
}

Wpłyną: 26.01.2020. Akceptacja: 20.07.2020

\section{Streszczenie}

Celem niniejszego artykułu jest przede wszystkim udzielenie odpowiedzi na pytanie, w jaki sposób sąd rozstrzyga o władzy rodzicielskiej w wyrokach rozwodowych w porównaniu z wyrokami orzekającymi separację. Przeanalizowano również, czy sąd zarówno w sprawach rozwodowych, jak i w sprawach o separację w sposób należyty (dokładnie i wyczerpująco) prowadzi postępowanie dowodowe, z wykorzystaniem wszystkich dostępnych i adekwatnych w danej sprawie środków dowodowych. W niniejszym artykule zawarte zostały rozważania teoretyczne dotyczące władzy rodzicielskiej w polskim prawie rodzinnym. Ponadto $\mathrm{w}$ artykule dokonano analizy badań własnych aktowych dotyczących spraw, $\mathrm{w}$ których Sąd rozstrzygał o władzy rodzicielskiej rozwiedzionych rodziców oraz małżonków pozostających w separacji.

Słowa kluczowe: rozwód, separacja, władza rodzicielska rozwiedzionych rodziców, władza rodzicielska małżonków pozostających w separacji.

1 Mgr Karolina Kulesza - Prawnicze Seminarium Doktorskie, Akademia Leona Koźmińskiego (Polska); e-mail: karolinakulesza@poczta.onet.pl; ORCID: 0000-0003-2035-4757.

2 Projekt badawczy nie jest finansowany przez żadną instytucję. 


\title{
KAROLINA KULESZA
}

\section{Way of resolving on the parental responsibility in the divorce sentence compared with the sentence adjudicating the separation ${ }^{3}$}

\begin{abstract}
The purpose of this article is, first of all, to answer the question of how the court determines parental authority in divorce judgments in comparison with judgments separating. It was also analyzed whether the court, in divorce matters and in matters relating to separation, duly and thoroughly carries out evidence proceedings, using all available and adequate evidence in a given case. This article contains theoretical considerations regarding parental authority in Polish family law. In addition, the article analyzes the author's own research - the files concerning cases in which the Court settled the parental authority of divorced parents and spouses separated.
\end{abstract}

Keywords: divorce, separation, parental authority of divorced parents, parental authority of spouses separated.

3 The research project is not funded by any institution. 


\section{Uwagi wstępne}

Powszechnie rodzina uznawana jest za naturalną i podstawową komórkę społeczną, która w szczególności stanowi niezastąpione środowisko rozwoju dziecka. W preambule Konwencji o prawach dziecka czytamy, iż „dla pełnego i harmonijnego rozwoju osobowości dziecka, powinno ono wychowywać się w środowisku rodzinnym, w atmosferze szczęścia, miłości i zrozumienia"4 Jak podkreśla W. Stojanowska, „rodzina jest podstawową komórką społeczną, która wymaga rzeczywistej ochrony i zapewnienia wnikliwości przy rozpoznawaniu jej spraw przez sąd"5.

Rozwód, w „pełnym rozumieniu oddziałuje przede wszystkim w dwóch sferach: małżeńskiej oraz rodzicielskiej" ${ }^{\prime \prime}$. Literatura przedmiotu wskazuje, że w sferze małżeńskiej rozwód likwiduje relacje między małżonkami o charakterze osobistym oraz stabilizuje zarówno ustające, jak i trwające po rozwodzie między stronami stosunki majątkowe. Przede wszystkim wskutek rozwodu m.in.: ustaje małżeństwo, pojawia się możliwość zawarcia nowego małżeństwa, ustają prawa i obowiązki osobiste między małżonkami, a także ustaje wspólność majątkowa. W sferze rodzicielskiej wyodrębnione zostały trzy zagadnienia: władza rodzicielska, kontakty z dzieckiem oraz występujący wobec niego obowiązek alimentacyjny ${ }^{7}$.

Instytucja rozwodu została wprowadzona w polskim prawie rodzinnym i opiekuńczym dekretem Prawo małżeńskie z dnia 25 września 1945 r. Obowiązujący Kodeks rodzinny i opiekunczy z 25 lutego 1964 r., wszedł w życie 1 stycznia 1965 r. „Utrzymał on w całej rozciągłości instytucję rozwodów. Zasady, które leżały u podstaw poprzednich przepisów, zostały zachowane. Zmieniona została, co prawda, redakcja przepisów dotyczących rozwodu, lecz nie miało to większego znaczenia w zakresie sądowego rozstrzygania spraw rozwodowych" ${ }^{\prime 8}$. Rozwód uważany jest za instytucję prawną pozwalającą rozwiązać małżeństwo za życia małżonków. W świetle orzecznictwa Sąd Najwyższy w Wytycznych z 1987 r. wskazał, iż „mał-

$4 \quad$ Konwencja o prawach dziecka przyjęta przez Zgromadzenie Ogólne Narodów Zjednoczonych z dnia 20.11.1989 r., Dz.U. z 1991 r. Nr 120, poz. 526 z późn. zm.

5 W. Stojanowska, Rozwód a ochrona rodziny i dziecka - wybrane zagadnienia, „Rodzina i Prawo” 2008, 7-8, s. 16.

6 T. Sokołowski, Rozwód, [w:] T. Smyczyński (red.), System prawa prywatnego. Prawo rodzinne i opiekuńcze, t. 11, wyd. 2, Warszawa 2014, s. 575.

7 Ibidem, s. 595.

8 Z. Krzemiński, Rozwód. Komentarz do przepisów, orzecznictwo, piśmiennictwo, Kraków 2001, s. 20. 
żeństwo jest związkiem dwojga osób, obejmującym w zasadzie całość ich życia. Cel i społeczne znaczenie związku małżeńskiego wymagają, aby niektóre konsekwencje jego zawarcia trwały nawet po rozwiązaniu małżeństwa"9.

$\mathrm{Z}$ art. 58 k.r.o., który zobowiązuje sąd do wszechstronnego uregulowania w wyroku rozwodowym całokształtu spraw małżeńskich, rodzicielskich, alimentacyjnych, mieszkaniowych oraz majątkowych rozpadającej się rodziny, wynika zasada integralności wyroku rozwodowego. Jak podkreśla SN, zgodnie ze wskazaną zasadą sprawa rozwodowa nie jest wyłącznie sprawą o rozwiązanie małżeństwa, lecz sprawą, w której Sąd orzeka o „całości spraw rodziny”10.

Na gruncie polskiego prawa rodzinnego obok rozwodu wyróżniamy instytucję separacji, która unormowana była w dekrecie z 25 września 1945 r. Prawo małżeńskie, jednak w krótkim czasie usunięto ją z polskiego prawa rodzinnego. Ponownie została wprowadzona do Kodeksu rodzinnego i opiekuńczego ustawą z 21 maja 1999 r. o zmianie ustawy Kodeks rodzinny i opiekuńczy ${ }^{11}$. Obecnie instytucję separacji regulują przepisy od art. $61^{1}$ do art. $61^{6}$ k.r.o. „Jedną z ważniejszych konsekwencji orzeczenia separacji jest zwolnienie małżonków z obowiązku wspólnego pożycia"12.

Z prawnego punktu widzenia każdy z małżonków może żądać, ażeby sąd rozwiązał małżeństwo przez rozwód wówczas, gdy nastąpił zupełny i trwały rozkład pożycia małżeńskiego. Kierując się powszechnie stosowaną klasyfikacją przesłanek rozwodu, na podstawie art. $61^{1} \S 1$ k.r.o. wyróżniamy pozytywną przesłankę separacji spełnioną wówczas, gdy między małżonkami nastąpił zupełny rozkład pożycia małżeńskiego. W przypadku separacji cecha trwałości rozkładu pożycia nie jest konieczna jak przy rozwodzie. Z orzeczeniem rozwodu oraz separacji łączą się konsekwencje prawne dotyczące stosunków rodzinnych, których uczestnikami są dzieci pochodzące od małżonków albo przez nich przysposobione. Przede wszystkim wyróżnia się takie zagadnienia, jak władza rodzicielska oraz kontakty z dzieckiem małżonków po orzeczeniu rozwodu lub separacji ${ }^{13}$.

W świetle doktryny separacja jest traktowana m.in. jako instytucja stanowiąca pomoc dla małżonków, których związek znajduje się w kryzysowej sytuacji. Artykuł $61^{1} \S 1$ k.r.o. stanowi, że "Jeżeli między małżonkami nastąpił zupełny rozkład pożycia, każdy z małżonków może żądać, ażeby Sąd orzekł separację”. Orzeczenie

\footnotetext{
$9 \quad$ Uchwała SN z dnia 16.12.1987 r., III CZP 91/86, OSNCP 1988, Nr 4, poz. 42.

10 Uchwała SN z dnia 12.10.1970 r., III CZP 6/70, OSNCP 1971, Nr 7-8, poz. 117.

11 Ustawa z dnia 21.05.1999 r. o zmianie ustaw Kodeks rodzinny i opiekuńczy, Kodeks cywilny, Kodeks postępowania cywilnego oraz niektórych innych ustaw, Dz.U. z 1999 r. Nr 52, poz. 532.

12 J. Panowicz-Lipska, Separacja, [w:] T. Smyczyński (red.), op. cit., Warszawa 2014, s. 876.

13 Ibidem, s. 938.
} 
separacji nie przesądza o dalszych losach małżeństwa trwającego po jej orzeczeniu, mimo że ustaje większość praw i obowiązków małżeńskich ${ }^{14}$. Rezultat skorzystania przez małżonków z instytucji separacji polega przede wszystkim na kompleksowym uregulowaniu ich sytuacji przez modyfikację stosunku prawnego ze względu na zakłócenia w funkcjonowaniu małżeństwa, przy zachowaniu w dalszym ciągu węzła małżeńskiego ${ }^{15}$.

Wprowadzenie obok siebie instytucji rozwodu oraz separacji wymaga przede wszystkim określenia wzajemnych relacji między nimi. W doktrynie wyróżniamy dwa podstawowe modele określające zasady stosowania wskazanych instytucji. Według pierwszego modelu do ubiegania się o rozwód niezbędne jest pozostawanie małżonków przez pewien czas w formalnie ustanowionej separacji. Cechą charakterystyczną częściej występującego w praktyce drugiego modelu o przeważającym stosowaniu, w tym również w polskim prawie, jest ukształtowanie prawne rozwodu i separacji jako instytucji niezależnych. Adekwatnie do modelu niezależności, zgodnie z przepisami k.r.o., rozwód nie musi być poprzedzony separacją. Ponadto, orzeczenie separacji nie ogranicza małżonkom możliwości uzyskania rozwodu, a także nie ułatwia rozwiązania małżeństwa przez rozwód ${ }^{16}$.

Zgodnie z art. 439 § 1 i 2 k.p.c., niedopuszczalne jest powództwo wzajemne o rozwód lub o separację. Wskazany przepis stanowi, iż „,w czasie trwania procesu o rozwód lub o separację nie może być wszczęta odrębna sprawa o rozwód albo o separację". Artykuł 439 § 3 k.p.c. stanowi, iż strona pozwana w sprawie o rozwód może również żądać rozwodu albo separacji. Z kolei w sprawie o separację strona pozwana może żądać separacji albo rozwodu. Określone w k.r.o. reguły rozstrzygania o przeciwstawnych roszczeniach $w$ jednym postępowaniu stanowią, że w przypadku, gdy jeden z małżonków żąda orzeczenia rozwodu i to żądanie jest uzasadnione, a drugi orzeczenia separacji, wówczas sąd orzeka rozwód. Jeżeli natomiast, orzeczenie rozwodu nie jest dopuszczalne, a żądanie orzeczenia separacji jest uzasadnione, to sąd orzeka separację. Z powyższego wynika „zasada rozpoznawania w pierwszej kolejności żądania idącego dalej, jak również wynika konsekwencja złagodzenia przesłanek separacji w porównaniu z przesłankami rozwodu"17. Według art. $61^{3} \S 1$ k.r.o. przy orzekaniu o separacji stosuje się przepisy art. 57 i art. 58 tegoż kodeksu, odnoszące się do rozstrzygnięć wyroku rozwodowego. W związku z powyższym wyrok orzekający separację powinien rozstrzygać o winie rozkładu pożycia małżeńskiego, chyba że małżonkowie złożyli zgodny wniosek

\footnotetext{
14 E. Holewińska-Łapińska, Orzekanie separacji, Warszawa 2006, s. 75.

15 J. Panowicz-Lipska, op. cit., s. 876.

16 Ibidem, s. 890-893.

17 Ibidem, s. 892.
} 
o odstąpienie od orzekania, który z nich ponosi winę rozkładu pożycia. Wyrok orzekający separację powinien zawierać również rozstrzygnięcia dotyczące: władzy rodzicielskiej nad wspólnym małoletnim dzieckiem obojga małżonków, kosztów utrzymania i wychowania wspólnego dziecka, a także sposobu korzystania przez małżonków ze wspólnego mieszkania. Inne rozstrzygnięcia zamieszczane są w wyroku orzekającym separację na żądanie jednego lub obojga małżonków ${ }^{18}$.

\section{Instytucja władzy rodzicielskiej rozwiedzionych rodziców oraz małżonków pozostających w separacji nad ich małoletnimi dziećmi}

Treść władzy rodzicielskiej, a także wynikające z niej obowiązki zostały uregulowane w art. 95 k.r.o. W myśl wskazanego przepisu na treść władzy rodzicielskiej składają się: piecza nad osobą dziecka, piecza nad jego majątkiem oraz wychowanie dziecka. Ponadto, na podstawie art. 98 k.r.o. do treści władzy rodzicielskiej zaliczamy reprezentowanie dziecka będące prawem i zarazem obowiązkiem rodziców ${ }^{19}$. W literaturze przedmiotu podkreśla się, że przez pojęcie władzy rodzicielskiej należy rozumieć „ogół praw i obowiązków przysługujących rodzicom, wobec ich małoletnich dzieci w celu należytego sprawowania pieczy nad osobą dziecka i jego majątkiem, wychowania go oraz przygotowania do pracy odpowiednio do jego uzdolnień" ${ }^{20}$. Ponadto, zgodnie z treścią art. $95 \S 3$ k.r.o. „Władza rodzicielska powinna być wykonywana tak, jak tego wymaga dobro dziecka i interes społeczny".

Niewątpliwie konflikty między rodzicami, brak wspólnego pożycia małżonków, a więc i wspólnego zamieszkiwania rodziców z dziećmi zakłócają wspólne wykonywanie władzy rodzicielskiej ${ }^{21}$. W wyroku rozwodowym oraz w wyroku orzekającym separację sąd obligatoryjnie rozstrzyga o sposobie wykonywania władzy rodzicielskiej małżonków nad ich wspólnymi małoletnimi dziećmi. Przede wszystkim wymaga podkreślenia, że stosownie do art. $61^{3} \S 1$ k.r.o., zasady orzekania na podstawie art. 58 tegoż kodeksu poświęcone problematyce rozwodu, znajdują również odniesienie do orzekania o separacji. Zgodnie ze stanowiskiem doktryny

\footnotetext{
18 E. Holewińska-Łapińska, op. cit., s. 99.
}

19 M. Kosek, Wtadza rodzicielska i kontakty z dzieckiem, [w:] W. Stojanowska (red.), M. Kosek, Nowelizacja prawa rodzinnego na podstawie ustaw z 6 listopada2008 r. i 10 czerwca 2010 r. Analiza - wykładnia - komentarz, wyd. 1, Warszawa 2011, s. 227.

20 B. Dobrzański, [w:] B. Dobrzański, J. Ignatowicz (red.), Kodeks rodzinny i opiekuńczy. Komentarz, Warszawa 1975, s. 658.

21 T. Smyczyński, Prawo rodzinne i opiekuńcze, wyd. 7, Warszawa 2014, s. 158. 
i orzecznictwa wyróżniamy następujące sposoby rozstrzygnięcia o władzy rodzicielskiej w wyroku orzekającym rozwód albo separację: pozostawienie władzy rodzicielskiej obojgu rodzicom, ograniczenie władzy rodzicielskiej w trybie art. 58 k.r.o., ograniczenie władzy rodzicielskiej w trybie art. 109 k.r.o., zawieszenie władzy rodzicielskiej jednego lub obojga rodziców w trybie art. 110 k.r.o. oraz pozbawienie władzy rodzicielskiej jednego lub obojga rodziców zgodnie z art. 111 k.r.o. ${ }^{22}$.

Kodeks rodzinny i opiekuńczy nie zawierał wyraźnej regulacji instytucji pozostawienia władzy rodzicielskiej obojgu rodzicom. Możliwość takiego rozstrzygnięcia wprowadziła do k.r.o. nowela z 6 listopada 2008 r. Artykuł 58 § 1 k.r.o. przewiduje instytucję porozumienia małżonków o sposobie wykonywania władzy rodzicielskiej i utrzymywaniu kontaktów z dzieckiem po rozwodzie. Ponadto, stanowi, iż „rodzeństwo powinno wychowywać się wspólnie, chyba że dobro dziecka wymaga innego rozstrzygnięcia". Wskazany przepis w uprzednio obowiązującym stanie prawnym określał przesłanki dopuszczalności pozostawienia władzy rodzicielskiej obojgu rodzicom, do których zaliczane były: zgodny wniosek rodziców, zawarcie przez małżonków „porozumienia” oraz współdziałanie rodziców w sprawach dziecka. Przesłanka współdziałania rodziców w sprawach dziecka wykluczała możliwość pozostawienia władzy rodzicielskiej obojgu w przypadku konfliktu między nimi ${ }^{23}$. Zdaniem W. Stojanowskiej „koncepcja porozumienia rodziców nawiązuje do amerykańskiego wzorca tzw. "planu wychowawczego" będącego wynikiem negocjacji między rodzicami i dobrowolnego zobowiązania się przez nich przed sądem do określonego sposobu sprawowania władzy rodzicielskiej i utrzymywania kontaktów"24.

Nowelizacja Kodeksu rodzinnego i opiekuńczego z dnia 25 czerwca 2015 r., która weszła w życie 29 sierpnia 2015 r. zasadniczo zmieniła treść art. 58 tegoż kodeksu. Wprawdzie zachowana zostaje wskazana instytucja porozumienia, niemniej jednak nawet w przypadku jego braku, istnieje możliwość pozostawienia po rozwodzie władzy rodzicielskiej bez ograniczenia obojgu rodzicom. Jak wskazuje W. Stojanowska „nowe brzmienie art. 58 § 1a k.r.o. w praktyce przekreśla możliwość dalszej ewolucji instytucji porozumienia w kierunku uczynienia z niego podstawowego instrumentu ochrony dobra dziecka w przypadku rozwodu jego rodziców" ${ }^{\prime 25}$. Nowela z 2015 r. wprowadziła także zmiany w przepisach Kodeksu

22 W. Stojanowska, Rozwód, [w:] T. Smyczyński (red.), op. cit., s. 736.

23 Eadem, Rozwód, [w:] W. Stojanowska (red.), M. Kosek, op. cit., s. 70-71.

24 Ibidem, s. 73.

25 W. Stojanowska, Pozostawienie władzy rodzicielskiej obojgu rozwiedzionym rodzicom i problemy wynikające z takiego rozstrzygnięcia sądu, [w:] S. Godek, R. Kamińska (red.), Przyszłość rodziny w UE, wyd. 1, Warszawa 2017, s. 201. 
postępowania cywilnego, umożliwiając jednocześnie orzekanie tzw. pieczy naprzemiennej, polegającej na zamieszkiwaniu dziecka z każdym z rodziców w powtarzających się okresach ${ }^{26}$. Niewątpliwie głównym celem noweli z 2015 r. było wprowadzenie tzw. instytucji „pieczy naprzemiennej”, mimo iż nie została stworzona dla niej właściwa podstawa prawna. Jak wskazuje W. Stojanowska, „Kodeks postępowania cywilnego nie może regulować instytucji prawnych, których kreowanie jest domeną prawa materialnego - Kodeksu rodzinnego i opiekuńczego. Konkludując, należy stwierdzić, iż zastosowanie tzw. pieczy naprzemiennej w rezultacie byłoby bezprawne, bowiem Kodeks postępowania cywilnego nie może kreować takiej podstawy prawnej" 27.

\section{Analiza wyników badań własnych aktowych dotyczących spraw o rozwód oraz o separację, w których sąd orzekł o władzy rodzicielskiej rodziców ${ }^{28}$}

Przedstawione w niniejszym artykule wyniki badań własnych aktowych przeanalizowano w celu porównania sposobu rozstrzygnięcia o władzy rodzicielskiej w wyroku rozwodowym oraz w wyroku o separację. Analiza akt sądowych (60 akt spraw rozwodowych oraz 60 akt spraw o separację) umożliwiła zbadanie przebiegu procesu sądowego w sprawach rozwodowych oraz o separację, w których sąd rozstrzygał o władzy rodzicielskiej. Szczegółowe badanie tych okoliczności pozwoliło również odpowiedzieć na pytanie, czy sąd wnikliwie przeprowadził postępowanie dowodowe, zarówno w sprawach rozwodowych, jak i o separację, z wykorzystaniem wszystkich dostępnych środków dowodowych oraz jakie środki dowodowe zastosował sąd w celu rozstrzygnięcia o władzy rodzicielskiej nad

26 Należy podkreślić, że zarówno SN jak i Stowarzyszenie Sędziów Polskich „Iustitia” wyrażali swoje negatywne stanowisko dotyczące instytucji „pieczy naprzemiennej”. Zob. Stanowisko Stowarzyszenia Sędziów Polskich „Iustitia” wobec projektu z 23.09.2014 r. założeń projektu ustawy o zmianie ustawy - Kodeks rodzinny i opiekuńczy, www.sejm.gov.pl. Zostało to sformułowane w następujący sposób: „(...) Z dużą jednak ostrożnością należy potraktować zmiany zmierzające do wprowadzenia tzw. pieczy naprzemiennej, bowiem jest to rozwiązanie obciążone dużym ryzykiem błędu, wiążące się z szerokimi konsekwencjami natury psychologicznej, praktycznej i prawnej." Z aprobatą cytowała to stanowisko W. Stojanowska, Pozostawienie władzy rodzicielskiej..., s. 205.

27 Ibidem, s. 206-207.

28 Źródłem przedstawionej powyżej analizy wyników badań własnych aktowych jest moja praca magisterska pt. „Sposób rozstrzygnięcia o władzy rodzicielskiej w wyrokach rozwodowych w porównaniu z wyrokami orzekającymi separację w świetle badań aktowych", napisana pod kierunkiem prof. zw. dr hab. W. Stojanowskiej, obroniona w Akademii Leona Koźmińskiego w Warszawie w 2017 r. 
małoletnimi dziećmi. Ponadto, zebrane wyniki badań pozwoliły na ustalenie, czy w badanych sprawach sąd orzekał o kontaktach z dzieckiem.

Wyniki przeprowadzonych badań wskazują, że zarówno w przypadku postępowania o rozwód, jak i o separację najczęściej powództwo wytaczała żona. Należy zauważyć, iż w 46 sprawach o rozwód $(76,7 \%)$ z pozwem wystąpiła żona, a w 14 sprawach $(23,3 \%)$ powodem był mąż. Podobnie kształtowała się sytuacja w przypadku spraw o separację. W 50 sprawach $(83,3 \%)$ pozew wniosła żona, natomiast tylko w 10 sprawach $(16,7 \%)$ powodem był mąż. Warto zaznaczyć, że w większości spraw małżonek wnosił o orzeczenie separacji ze względu na światopogląd religijny oraz przekonanie o braku zgody współmałżonka na rozwód. Analizując wyniki przeprowadzonych badań, należy zwrócić uwagę, iż zarówno w sprawach rozwodowych (70\%), jak również w sprawach o separację (55\%), na pierwszym miejscu znaleźli się małżonkowie mający jedno wspólne małoletnie dziecko. Warto podkreślić, że jedynie w 12 sprawach (20\%) małżonkowie występujący z pozwem o rozwód posiadali dwoje małoletnich dzieci. W porównaniu do spraw rozwodowych liczniejszą grupę w sprawach o separację stanowili malżonkowie mający dwoje małoletnich dzieci (33,3\%). Z badań wynika, iż w sprawach rozwodowych (10\%) oraz w sprawach o separację (11,7\%) w mniejszości znaleźli się małżonkowie mający troje małoletnich dzieci.

Przeprowadzone badania własne aktowe pozwoliły na ustalenie, iż wiek małoletnich dzieci w odniesieniu do spraw rozwodowych i spraw o separację kształtował się odmiennie. Najczęściej $(25,3 \%)$ dzieci małżonków występujących z pozwem o rozwód znajdowały się w przedziale wiekowym ponad 6 do 9 lat. W przypadku spraw o separację najliczniejszą grupą $(21,3 \%)$ były dzieci w wieku ponad 12 do 15 lat. W sprawach rozwodowych kolejną grupę (19,3\%) stanowiły dzieci w wieku ponad 3 do 6 lat. Drugą grupą $(19,1 \%)$ w sprawach o separację byli nieletni w wieku ponad 15 lat. Mniej liczną grupę w sprawach rozwodowych stanowiły dzieci $\mathrm{w}$ wieku ponad 12 do 15 lat $(18,1 \%)$, natomiast w sprawach o separację dzieci w wieku ponad 6 do 9 lat $(18,1 \%)$. Zarówno w sprawach rozwodowych (6\%), jak i w sprawach o separację (5,3\%) najmniej było dzieci w przedziale wiekowym do 1 roku. W sprawach rozwodowych najliczniejszą grupę dzieci stanowili małoletni w wieku ponad 6 do 9 lat (25,3\%), a najmniej liczną do 1 roku (6\%). Wyniki badań wskazują, że w sprawach o separację, najliczniejszą grupę stanowiły dzieci w wieku ponad 12 do 15 lat $(21,3 \%)$, a najmniej było, tak jak w przypadku spraw rozwodowych, dzieci znajdujących się w przedziale wiekowym do 1 roku (5,3\%). Podsumowując, stwierdzić należy, że dzieci małżonków w sprawach o separację były starsze niż dzieci małżonków w sprawach rozwodowych.

Omawiając wyniki przeprowadzonych badań, warto również zwrócić uwagę na wiek małżonków w chwili wszczęcia postępowania w badanych sprawach 
o rozwód oraz o separację. Zarówno w sprawach rozwodowych $(46,7 \%)$, jak i w sprawach o separację $(48,3 \%)$ najliczniejszą grupę wśród kobiet stanowiły żony znajdujące się w przedziale wiekowym ponad 30 do 40 lat, a najmniejszą w sprawach rozwodowych kobiety $w$ wieku ponad 50 lat $(1,6)$, natomiast $w$ sprawach o separację $\mathrm{w}$ wieku ponad 18 do 24 lat $(3,3 \%)$. W przypadku mężczyzn sytuacja przedstawiała się nieco inaczej. W sprawach rozwodowych najwięcej było mężczyzn w wieku ponad 30 do 40 lat (53,3\%), a najmniej w wieku ponad 50 lat (5\%). Odmiennie sytuacja kształtowała się w sprawach o separację, najliczniejszą grupę stanowili mężczyźni w wieku ponad 40 do 50 lat, natomiast najmniej liczną w wieku ponad 18 do 24 lat $(1,7 \%)$.

Tabela 1. Sytuacja prawna małżonków poprzedzająca wniesienie pozwu do Sądu w badanych sprawach o rozwód oraz o separację

\begin{tabular}{lrrrrr}
\hline & \multirow{2}{*}{ L.p. } & Sytuacja prawna małżonków & \multicolumn{2}{c}{ rozwód } & \multicolumn{2}{c}{ separacja } \\
\cline { 3 - 6 } & & w l.b. & w \% & w l.b. & w \% \\
\hline 1. & pierwsze małżeństwo dla obojga małżonków & 23 & 38,4 & 24 & 40 \\
\hline 2. & kolejne małżeństwo dla obojga małżonków & 2 & 3,3 & 0 & 0 \\
\hline 3. & pierwsze małżeństwo dla żony, natomiast drugie dla męża & 2 & 3,3 & 1 & 1,7 \\
\hline 4. & pierwsze małżeństwo dla męża, natomiast drugie dla żony & 0 & 0 & 2 & 3,3 \\
\hline 5. & nie wynika z akt & 33 & 55 & 33 & 55 \\
\hline & Ogółem & 60 & 100 & 60 & 100 \\
\hline
\end{tabular}

Źródło: Opracowanie własne.

Z tabeli nr 1 wynika, iż w większości badanych spraw (55\%) brakowało informacji umożliwiających ustalenie sytuacji prawnej małżonków poprzedzającej wniesienie do sądu pozwu o rozwód oraz o separację. Ponadto, jak wynika z zamieszczonych danych, zarówno w sprawach rozwodowych $(38,4 \%)$, jak i w sprawach o separację (40\%) aktualny związek małżeński był pierwszym małżeństwem dla obojga małżonków. $W$ aktach badanych spraw o rozwód nie było żadnego przypadku, w którym obecne małżeństwo byłoby pierwszym małżeństwem dla męża, natomiast drugim dla żony. Wiadomo, że w dwóch spośród zbadanych spraw $(3,3 \%)$ obecne małżeństwo było kolejnym dla obojga małżonków, oraz dla dwóch żon w sprawach rozwodowych (3,3\%) aktualne małżeństwo było kolejnym. Inaczej kształtowała się sytuacja w sprawach o separację. W tej grupie spraw nie było żadnej, w której obecne małżeństwo byłoby kolejnym dla obojga małżonków. 
W jednej sprawie (1,7\%) aktualne małżeństwo było pierwszym dla żony, natomiast drugim dla męża. $Z$ kolei w dwóch sprawach (3,3\%) żona przed zawarciem małżeństwa, którego dotyczył proces o separację, pozostawała w innym związku małżeńskim. $Z$ badanych akt spraw nie wynikało, jakie były przyczyny orzeczenia rozwodu wcześniejszych małżeństw.

Tabela 2. Dowody przeprowadzone przez sąd w toku postępowania o rozwód oraz o separację w badanych sprawach

\begin{tabular}{|c|c|c|c|c|c|}
\hline \multirow{2}{*}{ L.p. } & \multirow{2}{*}{$\begin{array}{l}\text { Dowody przeprowadzone przez Sąd } \\
\text { w toku procesu }\end{array}$} & \multicolumn{2}{|c|}{ rozwód } & \multicolumn{2}{|c|}{ separacja } \\
\hline & & w l.b. & w \% & w l.b. & $w \%$ \\
\hline 1. & dowód z przesłuchania stron & 60 & 100 & 59 & 98,3 \\
\hline 2. & dowód $z$ dokumentu & 21 & 35 & 31 & 51,7 \\
\hline 3. & $\begin{array}{l}\text { dowód z przeprowadzonych wywiadów } \\
\text { środowiskowych oraz opinii z Rodzinnego Ośrodka } \\
\text { Diagnostyczno-Konsultacyjnego (obecna nazwa } \\
\text { Opiniodawczy Zespół Specjalistów Sądowych - OZSS) }\end{array}$ & 13 & 21,7 & 1 & 1,67 \\
\hline 4. & dowód z przesłuchania świadków & 57 & 95 & 55 & 91,67 \\
\hline & Ogółem* & \multicolumn{2}{|c|}{$\begin{array}{l}\text { Łączna liczba } \\
\text { przeprowadzonych } \\
\text { dowodów } 151\end{array}$} & \multicolumn{2}{|c|}{$\begin{array}{l}\text { Łączna liczba } \\
\text { przeprowadzonych } \\
\text { dowodów } 146\end{array}$} \\
\hline
\end{tabular}

\footnotetext{
*Wynik nie sumuje się do 60 l.b., ponieważ mogło być przeprowadzonych więcej dowodów w jednej sprawie. Źródło: Opracowanie własne.
}

Dane przedstawione w tabeli 2 wskazują, iż we wszystkich sprawach o rozwód (100\%) zostały przesłuchane obie strony. W jednej sprawie o separację nie został przeprowadzony dowód z przesłuchania stron z uwagi na fakt, iż pozwany przebywał za granicą i nie ustalono miejsca jego pobytu. Szczegółowa analiza badanych spraw pozwoliła na ustalenie, iż równie licznym dowodem przeprowadzonym wśród spraw rozwodowych $(95 \%)$ oraz spraw o separację $(91,67 \%)$ był dowód z przesłuchania świadków. W badanych sprawach świadkami najczęściej byli: krewni strony powodowej, krewni strony pozwanej, osoby zaprzyjaźnione z małżonkami oraz współpracownicy małżonków. Zarówno w sprawach rozwodowych (35\%), jak również w sprawach o separację $(51,7 \%)$ w toku postępowania został przeprowadzony dowód z dokumentu. Wśród załączonych dokumentów były przede wszystkim: skrócone odpisy aktu małżeństwa, skrócone odpisy aktu urodzenia dzieci, dokumenty wskazujące na stan zdrowia dziecka bądź małżonka, zaświadczenia o wysokości zarobków małżonków. W nielicznych sprawach roz- 
wodowych $(21,7 \%)$ został przeprowadzony przez kuratora sądowego wywiad środowiskowy oraz dowód w postaci opinii Rodzinnego Ośrodka Diagnostyczno-Konsultacyjnego (obecnie: Opiniodawczy Zespól Sądowych Specjalistów - OZSS). Tylko w jednej sprawie o separację (1,67\%) Sąd przeprowadził dowód z wywiadu kuratora sądowego oraz opinii ROD-K. Podsumowując, należy zwrócić uwagę, że zakres postępowania dowodowego w zbadanych sprawach był ograniczony. Głównym dowodem było przesłuchanie stron i świadków. Najczęściej świadkami byli krewni strony powodowej oraz krewni strony pozwanej.

Szczegółowa analiza badanych spraw wskazuje, że najwięcej spraw rozwodowych zostało rozpoznanych w okresie ponad rok do dwóch lat (25\%). Należy również stwierdzić, że równie liczną grupę stanowią sprawy o rozwód rozpoznane w okresie od 6 do 9 miesięcy $(21,7 \%)$. W 12 sprawach wyrok rozwodowy został wydany w okresie od 3 do 6 miesięcy od dnia wniesienia pozwu. Taka sama była liczba spraw rozwodowych (13,3\%), w których czas rozpoznania wynosił od 9 do 12 miesięcy oraz ponad 2 lata. Najmniej było spraw rozwodowych, w których czas postępowania był krótszy niż 3 miesiące. Inaczej kształtował się czas trwania postępowania o separację. Najliczniejsze były sprawy, w których postępowanie trwało od 3 do 6 miesięcy oraz od 6 do 9 miesięcy (26,7\%). W równie licznej grupie znajdowały się sprawy, których czas postępowania wynosił od roku do 2 lat $(16,6 \%)$ oraz od 9 do 12 miesięcy (13,3\%). Nieliczne były sprawy o separację, w których czas trwania postępowania przekraczał 2 lata (10\%), a także sprawy rozpoznane w czasie krótszym niż 3 miesiące $(6,7 \%)$.

Z przeprowadzonych badań własnych aktowych można wnioskować, że $\mathrm{w}$ ponad połowie badanych spraw rozwodowych (55\%) oraz spraw o separację $(57,4 \%)$ sąd zaniechał orzekania o winie rozkładu pożycia małżeńskiego. W 20 wyrokach o separacji (33,3\%), sąd orzekł wyłączną winę pozwanego. W większości z tych spraw pozwanym był mąż. Jedynie w 6 sprawach $(9,3 \%)$ orzeczona została wina obojga małżonków. Wśród akt spraw o separację, objętych niniejszą analizą nie było żadnej sprawy, w której została orzeczona wyłączna wina powoda. Inaczej kształtuje się sytuacja w sprawach rozwodowych. Spośród wszystkich spraw w 13 przypadkach $(21,6 \%)$ sąd orzekł wyłączną winę pozwanego. Równie liczne były sprawy rozwodowe, w których orzeczona została wyłączna wina powoda $(11,7 \%)$, a także orzeczona została wina obojga małżonków $(11,7 \%)$.

Reasumując, zarówno w sprawach rozwodowych, jak i w sprawach o separację w większości przypadków sąd zaniechał orzekania o winie rozkładu pożycia małżeńskiego. Należy przypuszczać, że małżonkowie występujący z pozwem o rozwód oraz o separację w głównej mierze decydują się na zaniechanie orzekania o winie $z$ uwagi na fakt, że postępowanie takie jest mniej skomplikowane i trwa znacznie krócej. 
Niewątpliwie wraz z orzeczeniem rozwodu oraz separacji łączy się rozstrzygnięcie dotyczące zasądzenia alimentów. We wszystkich sprawach o separację sąd zasądził od pozwanego alimenty wyłącznie na rzecz małoletniego dziecka małżonków. Wśród zbadanych spraw o separację nie było żadnej sprawy, w której sąd zasądził alimenty od pozwanego na rzecz byłego małżonka. Jedynie w dwóch sprawach o rozwód sąd zasądził alimenty na rzecz byłego małżonka.

Wyniki przeprowadzonych badań wskazują, że w nielicznych sprawach rozwodowych (20\%) oraz sprawach o separację (15\%) sąd wydał postanowienie o zabezpieczeniu powództwa na czas trwania procesu. Przede wszystkim w większości spraw rozwodowych, jak również spraw o separację, małżonkowie nie występowali z wnioskiem o zabezpieczenie powództwa na czas trwania procesu. Prawdopodobnie wynika to z braku świadomości prawnej, tj. wiedzy o możliwości wystąpienia z owym żądaniem. W nielicznych sprawach żądanie małżonka o zabezpieczenie powództwa zostało przez sąd oddalone.

Z akt spraw poddanych analizie uzyskano również informacje dotyczące występowania między małżonkami sporu o władzę rodzicielską $w$ badanych sprawach o rozwód oraz o separację. W zdecydowanej większości spraw rozwodowych (80\%) oraz spraw o separację $(91,7 \%)$ małżonkowie byli zgodni w kwestii rozstrzygnięcia o władzy rodzicielskiej nad wspólnymi małoletnimi dziećmi. Jedynie w 5 sprawach o separację $(8,3 \%)$ między małżonkami występował spór o władzę rodzicielską. Widoczna jest różnica w odniesieniu do spraw rozwodowych, bowiem w 12 sprawach o rozwód (20\%) małżonkowie nie byli zgodni w kwestii władzy rodzicielskiej.

Kluczowym zagadnieniem dla celów omawianych badań, jak też niniejszego artykułu, był sposób rozstrzygnięcia o władzy rodzicielskiej w wyrokach rozwodowych oraz w wyrokach orzekających separację. Wyniki badań w tym przedmiocie zostały przedstawione $\mathrm{w}$ tabeli 3 . We wszystkich badanych sprawach sąd rozstrzygał o władzy rodzicielskiej małoletnich dzieci małżonków. Zarówno w sprawach rozwodowych $(78,2 \%)$, jak i w sprawach o separację $(76,7 \%)$ sąd, rozstrzygając o władzy rodzicielskiej, pozostawiał władzę rodzicielską obojgu małżonkom z jednoczesnym ustaleniem miejsca pobytu dziecka u matki. Jedynie w 4 $(6,6 \%)$ sprawach o separację sąd pozostawił władzę rodzicielską obojgu małżonkom $\mathrm{z}$ jednoczesnym ustaleniem miejsca pobytu dziecka u ojca.

W przypadku spraw rozwodowych (10\%) i spraw o separację (13,3\%) sąd, orzekając o władzy rodzicielskiej, powierzał władzę rodzicielską matce, natomiast władzę rodzicielską ojca ograniczał do określonych obowiązków i uprawnień w stosunku do osoby dziecka. Tylko w jednej sprawie o separację (1,7\%) sąd orzekł pozbawienie władzy rodzicielskiej wobec matki. Również w tylko jednej sprawie sąd, orzekając o władzy rodzicielskiej, ograniczył władzę rodzicielską ojca, poddając jednocześnie wykonywanie władzy rodzicielskiej stałemu nadzorowi kuratora sądowego. 
Tabela 3. Sposób rozstrzygnięcia o władzy rodzicielskiej w badanych sprawach rozwodowych oraz o separację

\begin{tabular}{|c|c|c|c|c|c|}
\hline \multirow{2}{*}{ L.p. } & \multirow{2}{*}{ Sposób rozstrzygnięcia o władzy rodzicielskiej } & \multicolumn{2}{|c|}{ rozwód } & \multicolumn{2}{|c|}{ separacja } \\
\hline & & w l.b. & $w \%$ & w l.b. & $w \%$ \\
\hline 1. & $\begin{array}{l}\text { pozostawienie władzy rodzicielskiej obojgu małżonkom } \\
\text { - miejsce pobytu dzieci u matki }\end{array}$ & 47 & 78,2 & 46 & 76,7 \\
\hline 2. & $\begin{array}{c}\text { pozostawienie władzy rodzicielskiej obojgu małżonkom } \\
\text { - miejsce pobytu dzieci u ojca }\end{array}$ & 0 & 0 & 4 & 6,6 \\
\hline 3. & $\begin{array}{c}\text { powierzenie władzy rodzicielskiej matce, a ograniczenie } \\
\text { władzy rodzicielskiej ojcu do określonych obowiązków } \\
\text { i uprawnień w stosunku do osoby dziecka }\end{array}$ & 6 & 10 & 8 & 13,3 \\
\hline 4. & $\begin{array}{l}\text { powierzenie władzy rodzicielskiej ojcu, a ograniczenie } \\
\text { władzy rodzicielskiej matce do określonych obowiązków } \\
\text { i uprawnień w stosunku do osoby dziecka }\end{array}$ & 3 & 5 & 0 & 0 \\
\hline 5. & zawieszenie władzy rodzicielskiej wobec matki & 0 & 0 & 0 & 0 \\
\hline 6. & zawieszenie władzy rodzicielskiej wobec ojca & 1 & 1,7 & 0 & 0 \\
\hline 7. & pozbawienie władzy rodzicielskiej matki & 0 & 0 & 1 & 1,7 \\
\hline 8. & pozbawienie władzy rodzicielskiej ojca & 1 & 1,7 & 0 & 0 \\
\hline 9. & $\begin{array}{l}\text { ograniczenie władzy rodzicielskiej matce } \\
\text { w trybie art. } 109 \text { k.r.o. }\end{array}$ & 1 & 1,7 & 0 & 0 \\
\hline 10. & $\begin{array}{l}\text { ograniczenie władzy rodzicielskiej ojcu } \\
\text { w trybie art. } 109 \text { k.r.o. }\end{array}$ & 1 & 1,7 & 1 & 1,7 \\
\hline & Ogółem & 60 & 100 & 60 & 100 \\
\hline
\end{tabular}

Źródło: Opracowanie własne.

Odmiennie kształtowała się sytuacja wśród spraw rozwodowych. W 3 sprawach (5\%) sąd powierzył wykonywanie władzy rodzicielskiej ojcu, a ograniczył władzę rodzicielską matki do określonych uprawnień i obowiązków dotyczących osoby dziecka. W sprawach o rozwód rozstrzygnięcia sądu o zawieszeniu oraz pozbawieniu władzy rodzicielskiej ojca stanowiły $1,7 \%$ wszystkich zbadanych spraw. Jak wynika z tabeli $3 \mathrm{w}$ jednej ze spraw rozwodowych $(1,7 \%)$ sąd ograniczył władzę rodzicielską matki w trybie art. 109 k.r.o., poddając jednocześnie wykonywanie władzy rodzicielskiej stałemu nadzorowi kuratora sądowego.

Podsumowując, najczęściej zarówno wśród spraw rozwodowych, jak i spraw o separację sąd, orzekając o władzy rodzicielskiej, pozostawiał władzę rodzicielską obojgu małżonkom z jednoczesnym ustaleniem miejsca pobytu dzieci u matki. Odnośnie do spraw o rozwód oraz spraw o separację równie licznie występowały 
rozstrzygnięcia o powierzeniu wykonywania władzy rodzicielskiej matce, a ograniczeniu władzy rodzicielskiej ojca do określonych uprawnień i obowiązków dotyczących osoby dziecka.

Tabela 4. Informacje dotyczące rozdzielenia rodzeństwa przez sąd orzekający o władzy rodzicielskiej w badanych sprawach o rozwód oraz o separację

\begin{tabular}{|c|c|c|c|c|c|}
\hline \multirow{2}{*}{ L.p. } & \multirow{2}{*}{ Rozdzielenie rodzeństwa } & \multicolumn{2}{|c|}{ rozwód } & \multicolumn{2}{|c|}{ separacja } \\
\hline & & w l.b. & w \% & w l.b. & w \% \\
\hline 1. & $\begin{array}{c}\text { Sąd, orzekając o władzy rodzicielskiej, } \\
\text { rozdzielił rodzeństwo }\end{array}$ & 0 & 0 & 1 & 1,6 \\
\hline 2. & $\begin{array}{c}\text { Sąd, orzekając o władzy rodzicielskiej, } \\
\text { nie rozdzielił rodzeństwa }\end{array}$ & 17 & 28,3 & 23 & 38,4 \\
\hline 3. & nie dotyczy & 43 & 71,7 & 36 & 60 \\
\hline & Ogółem & 60 & 100 & 60 & 100 \\
\hline
\end{tabular}

Źródło: Opracowanie własne.

W zdecydowanej większości spraw rozwodowych $(71,7 \%)$ oraz spraw o separację $(60 \%)$ badana kwestia nie występowała $z$ uwagi na fakt, iż małżonkowie występujący z pozwem mieli tylko jedno wspólne małoletnie dziecko. Zarówno w przypadku spraw rozwodowych $(28,3 \%)$, jak i w sprawach o separację $(38,4 \%)$, w których małżonkowie mieli co najmniej dwoje małoletnich dzieci, sąd, orzekając o władzy rodzicielskiej, nie rozdzielił rodzeństwa. Wśród badanych spraw, tylko w jednej sprawie o separację $(1,6 \%)$ sąd, orzekając o władzy rodzicielskiej, rozdzielił rodzeństwo. We wskazanej sprawie, małżonkowie mieli dwóch małoletnich synów. W chwili złożenia przez męża pozwu o separację, małżonkowie mieszkali w oddzielnych mieszkaniach. Młodszy syn małżonków mieszkał z powodem, natomiast starszy z pozwaną. Małżonkowie zawarli porozumienie o sposobie wykonywania władzy rodzicielskiej nad małoletnimi dziećmi, ustalając sposób kontaktowania się z dziećmi po orzeczeniu separacji. W badanej sprawie sąd pozostawił władzę rodzicielską nad małoletnimi dziećmi obojgu małżonkom, ustalając miejsce pobytu młodszego syna u ojca, natomiast starszego u matki.

Z rozstrzygnięciem o władzy rodzicielskiej rozwiedzionych rodziców oraz małżonków pozostających w separacji niewątpliwie związana jest kwestia ustalenia kontaktów z dzieckiem rodzica, któremu nie została powierzona władza rodzicielska. Z przeprowadzonych badań wynika, że w ponad połowie spraw rozwodowych, a także spraw o separację $w$ wydanym przez sąd wyroku nie znajdowało się rozstrzygnięcie odnośnie do sposobu ustalenia kontaktów z dzieckiem małżonka, 
którego władza rodzicielska została ograniczona do określonych obowiązków i uprawnień w stosunku do osoby dziecka. W licznej grupie spraw rozwodowych $(30 \%)$ i spraw o separację (20\%) ustalenia w przedmiocie kontaktów z dzieckiem zostały zamieszczone $\mathrm{w}$ protokole rozprawy $\mathrm{w}$ wyniku ustnych propozycji małżonków. $\mathrm{W}$ badanych sprawach dostrzegana jest różnica co do spraw, w których kontakty z dzieckiem zostały ustalone w planie wychowawczym rodziców. Wśród spraw rozwodowych były tylko 3 sprawy $(3,3 \%)$, w których kontakty z dzieckiem zostały ustalone w sporządzonym przez małżonków "planie wychowawczym”, a w przypadku spraw o separację - $11(18,3 \%)$.

\section{Uwagi końcowe}

Analiza wyników badań własnych aktowych umożliwiła szczegółową charakterystykę problematyki w sprawach rozwodowych oraz w sprawach o separację, w których sąd rozstrzygał o władzy rodzicielskiej małżonków nad ich małoletnimi dziećmi. Jak już wcześniej wspomniano, prawny model instytucji separacji przyjęty przez polskiego ustawodawcę zawiera elementy charakterystyczne dla instytucji rozwodu. Zarówno postępowanie w sprawach rozwodowych, jak również w sprawach o separację normowane jest w taki sam sposób.

Jak wynika z danych Głównego Urzędu Statystycznego, w 2015 r. separacja została prawomocnie orzeczona w 1700 sprawach, przy czym w tym samym roku sądy wydały ogółem 67296 wyroków rozwodowych ${ }^{29}$. Z powyższego wynika, że instytucja separacji w porównaniu $\mathrm{z}$ instytucją rozwodu jest wykorzystywana w niewielkim zakresie. Zatrważająca i ciągle wzrastająca liczba orzekanych rozwodów skłania do refleksji nad trwałością małżeństwa. Przeprowadzone badania własne aktowe wykazały, że w zdecydowanej większości spraw rozwodowych oraz spraw o separację z pozwem wystąpiła żona. Najczęściej małżonkowie objęci postępowaniem rozwodowym oraz o separację znajdowali się w przedziale wiekowym między 30 a 40 lat. Odnosząc się do rozstrzygnięcia o władzy rodzicielskiej w wydanych wyrokach, należy zaznaczyć, że w zdecydowanej większości spraw rozwodowych oraz o separację, sąd pozostawił władzę rodzicielską obojgu małżonkom, ustalając miejsce zamieszkania dzieci u matki. Z przedstawionych w niniejszym artykule wyników badań wynika także, iż liczba co do poszczególnych rodzajów rozstrzygnięcia sądu o władzy rodzicielskiej w odniesieniu do badanych instytucji jest porównywalna.

29 Główny Urząd Statystyczny, Rocznik Demograficzny 2016, Warszawa 2016, tab. 2 (32), ark. Druk 31, s. 188. 
Wśród najliczniej wskazywanych przyczyn rozkładu pożycia małżeńskiego w badanych sprawach o rozwód oraz o separację znalazły się: niezgodność charakterów, konflikty między małżonkami na tle finansowym oraz brak zainteresowania domem i rodziną. Jak już wskazano, na wskazywaną przez małżonków niezgodność charakterów jako przyczynę rozkładu pożycia małżeńskiego składa się szereg innych przyczyn, o których małżonkowie podczas procesu nie chcą mówić. Do najczęściej występujących zaliczamy przede wszystkim silną ingerencję ze strony innych członków rodziny lub bliskich znajomych małżonków.

Dodatkowo z kilkunastu akt spraw rozwodowych oraz spraw o separację objętych badaniem wynikało, iż głównym powodem skłaniającym młodych ludzi do zawarcia małżeństwa była ciąża narzeczonej. Wniosek ten potwierdzają badania przeprowadzone przez W. Stojanowską w ramach projektu pt. „Przyczyny rozwodów i sposoby prowadzące do zmniejszania ich liczby (zapobieganie rozwodogennej sytuacji, tj. pochopnemu zawieraniu związków małżeńskich oraz doprowadzanie do pojednania skłóconych małżonków)". Z badań W. Stojanowskiej wynika, iż „na zawarcie małżeństwa z powodu ciąży narzeczonej wskazało 13,3\% respondentów" ${ }^{30}$. Należy zgodzić się ze stanowiskiem autorki cytowanych badań, zgodnie z którym charakter wskazanej przyczyny stwarza sytuację rozwodogenną już w momencie zawierania małżeństwa. Na gruncie Kodeksu rodzinnego i opiekuńczego przepisem zapobiegającym pochopnemu zawieraniu małżeństw jest art. 10, który przewiduje dwie obligatoryjne przesłanki w przypadku udzielenia przez sąd zezwolenia na zawarcie małżeństwa kobiecie niemającej ukończonych lat osiemnastu. Zaliczamy do nich ważne powody oraz przeświadczenie sądu, że zawarcie małżeństwa będzie zgodne z dobrem założonej rodziny. Jak wskazuje W. Stojanowska, „,należałoby również wpływać na praktykę stosowania art. 10 k.r.o., dokonując jego wykładni w ten sposób, aby sąd był zobowiązany badać, czy ciąża narzeczonej była jedynym ważnym powodem zawarcia małżeństwa, a poza tym nie było żadnego emocjonalnego zaangażowania nupturientów (brak miłości - np. ciąża była wynikiem przypadkowego współżycia)"31.

Podsumowując dotychczasowe rozważania, można stwierdzić, że wskutek orzeczenia rozwodu bądź separacji między małżonkami niewątpliwie najbardziej cierpią ich wspólne małoletnie dzieci, niezależnie od tego, którą z tych dwóch instytucji wybrali ich rodzice. Należy podkreślić, iż fundamentalne zasady prawa rodzinnego, w szczególności zasada ochrony małżeństwa i rodziny oraz ochrony

\footnotetext{
30 W. Stojanowska, Prawne środki zapobiegania pochopnemu zawieraniu małżeństw w świetle badań socjologicznych, "Zeszyty Prawnicze UKSW" 2012, 12(3), s. 40.

31 Ibidem, s. 58.
} 
dobra dziecka, powinny być realizowane nie tylko w procesie o rozwód, ale również w toku postępowania o separację ${ }^{32}$.

\section{Bibliografia}

\section{Literatura}

Dobrzański B., [w:] B. Dobrzański, J. Ignatowicz (red.), Kodeks rodzinny i opiekuńczy. Komentarz, Warszawa 1975.

Główny Urząd Statystyczny, Rocznik Demograficzny 2016, Warszawa 2016.

Holewińska-Łapińska E., Orzekanie separacji, Warszawa 2006.

Kosek M., Wtadza rodzicielska i kontakty z dzieckiem, [w:] W. Stojanowska (red.), M. Kosek, Nowelizacja prawa rodzinnego na podstawie ustaw z 6 listopada 2008 r. i 10 czerwca 2010 r. Analiza - wyktadnia - komentarz, wyd. 1, Warszawa 2011.

Krzemiński Z., Rozwód. Komentarz do przepisów, orzecznictwo, piśmiennictwo, Kraków 2001. Panowicz-Lipska J., Separacja, [w:] T. Smyczyński (red.), System prawa prywatnego. Prawo rodzinne i opiekuńcze, t. 11, wyd. 2, Warszawa 2014.

Smyczyński T., Prawo rodzinne i opiekuńcze, wyd. 7, Warszawa 2014.

Sokołowski T., Rozwód, [w:] T. Smyczyński (red.), System prawa prywatnego. Prawo rodzinne i opiekuńcze, t. 11, wyd. 2, Warszawa 2014.

W. Stojanowska, Pozostawienie władzy rodzicielskiej obojgu rozwiedzionym rodzicom i problemy wynikające z takiego rozstrzygnięcia sądu, [w:] S. Godek, R. Kamińska (red.), Przyszłość rodziny $w$ UE, wyd. 1, Warszawa 2017.

Stojanowska W., Rozwód, [w:] T. Smyczyński (red.), System prawa prywatnego. Prawo rodzinne i opiekuńcze, t. 11, wyd. 2, Warszawa 2014.

Stojanowska W., Prawne środki zapobiegania pochopnemu zawieraniu małżeństw w świetle badań socjologicznych, "Zeszyty Prawnicze UKSW" 2012, 12(3).

Stojanowska W., Rozwód, [w:] W. Stojanowska (red.), M. Kosek, Nowelizacja prawa rodzinnego na podstawie ustaw z 6 listopada 2008 r. 110 czerwca 2010 r. Analiza -wykładnia - komentarz, wyd. 1, Warszawa 2011.

Stojanowska W., Sposób prowadzenia postępowania w sprawach o rozwód a ochrona matżeństwa, „Prawo Kanoniczne. Kwartalnik Prawno-Historyczny” 2010, 3-4.

Stojanowska W., Rozwód a ochrona rodziny i dziecka - wybrane zagadnienia, „Rodzina i Prawo" 2008, 7-8.

Stojanowska W., Rozwód a dobro dziecka, Warszawa 1979.

32 Eadem, Sposób prowadzenia postępowania w sprawach o rozwód a ochrona małżeństwa, „Prawo Kanoniczne. Kwartalnik Prawno-Historyczny" 2010, 3-4, s. 321. 


\section{Akty prawne}

Konwencja o prawach dziecka, przyjęta przez Zgromadzenie Ogólne Narodów Zjednoczonych z dnia 20.11.1989 r., (Dz.U. z 1991 r. Nr 120, poz. 526 z późn. zm).

Ustawa z dnia 17.11.1964 r. - Kodeks postępowania cywilnego (Dz.U. z 1964 r. Nr 43, poz. 296 z późn. zm).

Ustawa z dnia 25.02.1964 r. - Kodeks rodzinny i opiekuńczy (Dz.U. z 2012 r., poz. 788 z późn. zm.).

Ustawa z dnia 21.05.1999 r. o zmianie ustaw Kodeks rodzinny i opiekuńczy, Kodeks cywilny, Kodeks postępowania cywilnego oraz niektórych innych ustaw (Dz.U. z 1999 r. Nr 52, poz. 532 z późn. zm).

Ustawa z dnia 6.11.2008 r. o zmianie ustawy - Kodeks rodzinny i opiekuńczy oraz niektórych innych ustaw (Dz.U. z 2008 r. Nr 220, poz. 1431 z późn. zm).

\section{Orzecznictwo}

Orzeczenie SN z dnia 6 października 1951 r.. C 188/51, OSN 1952, Nr 3, poz. 72.

Orzeczenie SN z dnia 26 sierpnia 1958 r., III CR 327/57, RPEiS 1959, z. 3, s. 343.

Orzeczenie SN z dnia 13 stycznia 1953 r., C 1631/52, OSN 1954, poz. 9.

Orzeczenie SN z dnia 9 marca 1956 r., IV CR/55, OSNCK 1956, Nr 4, poz. 110.

Orzeczenie SN z dnia 31 grudnia 1951 r., C 625/51, NP. 1953, nr 5, s. 82.

Orzeczenie SN z dnia 7 stycznia 1969 r., II CR 528/68, OSN 1969, Nr 10, poz. 179.

Orzeczenie SN z dnia 15 maja 1967 r., III CR 54/67, OSPiKA 1968, Nr 3, poz. 57.

Orzeczenie SN z dnia 13 lipca 1987 r., III CZP 40/87, OSNCPiUS 1988, Nr 11, poz. 154.

Uchwała SN z dnia 16 grudnia 1987 r., III CZP 91/86, OSNCP 1988, Nr 4, poz. 42.

Uchwała SN z dnia 12 października 1970 r., III CZP 6/70, OSNCP 1971, Nr 7-8, poz. 117. Uchwała SN z dnia 18 marca 1968 r., III CZP 70/66, OSN 1968, Nr 5, poz. 77.

Wytyczne SN z dnia 28 maja 1955 r., I CO 5/55, OSN 1955, poz. 46. 